Abstracta Iranica Abstracta Iranica

Revue bibliographique pour le domaine irano-aryen

Volume 29 | 2008

Comptes rendus des publications de 2006

\title{
«From the Persepolis Fortification Archive Project, I: An Old Persian Administrative Tablet from the Persepolis Fortification ». ARTA, 2007.001, pp. 1-28.
}

\section{Rüdiger Schmitt}

\section{(2) OpenEdition}

Journals

Édition électronique

URL : http://journals.openedition.org/abstractairanica/24402

DOI : 10.4000/abstractairanica.24402

ISSN : 1961-960X

Éditeur :

CNRS (UMR 7528 Mondes iraniens et indiens), Éditions de l'IFRI

Édition imprimée

Date de publication : 15 mai 2008

ISSN : 0240-8910

Référence électronique

Rüdiger Schmitt, « «From the Persepolis Fortification Archive Project, I: An Old Persian Administrative Tablet from the Persepolis Fortification ». ARTA, 2007.001, pp. 1-28. », Abstracta Iranica [En ligne],

Volume 29 | 2008, document 24, mis en ligne le 15 septembre 2008, consulté le 26 septembre 2020.

URL : http://journals.openedition.org/abstractairanica/24402 ; DOI : https://doi.org/10.4000/

abstractairanica.24402

Ce document a été généré automatiquement le 26 septembre 2020.

Tous droits réservés 


\title{
« From the Persepolis Fortification Archive Project, I: An Old Persian Administrative Tablet from the Persepolis Fortification ». ARTA, 2007.001, pp. 1-28.
}

\author{
Rüdiger Schmitt
}

This well-documented article in the electronic journal ARTA is the publication of an administrative tablet (Fort. 1208-101, measuring ca. $40 \times 44 \times 18 \mathrm{~mm}$ ) discovered in the Persepolis Fortification Archive in 1933, but identified as written in old Persian cuneiform and language only in 2006; it is of some importance in that it is the first administrative record in Old Persian language known till now. It is thus inconsistent with the common opinion that the old Persian writing and language were only used for royal prestige purposes. As for its shape, the old Persian text is identical with that of the Elamite tablets; it is for the most part legible, but scarcely any word of the text can be understood although it is written in accordance with the orthographic rules. The

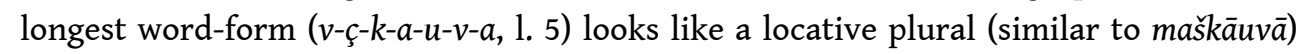
of a stem *vaçakā- or *Vaçakā- (being a toponym?); $x$-š-i-t- $h^{7}-[y-a]$ in 1.10 seems to be a

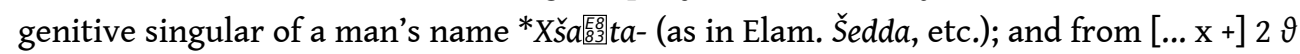
$-r^{7}-d-a$ at the end (1. 13) one may infer a date formula or (since one would expect in that case Yardam or Varda) rather a dual form Yardā " two years " referring to the disbursement (or sim.) of a two-year ration. This isolated old Persian text may display the strange behaviour of an individual administrative clerk just as it is the case with the one single Greek tablet found here, too. Of course the authors also discuss the consequences and the problems the new text raised as regards the use of the old Persian, Elamite, Aramaic or else languages in the Achaemenid Empire. 
INDEX

Thèmes : 2.1. Langues anciennes

\section{AUTEURS}

RÜDIGER SCHMITT

Laboe 